\title{
Karyotype analysis of three species of Allium (Amaryllidaceae) from Thailand
}

\author{
SURAPON SAENSOUK ${ }^{1}$, PIYAPORN SAENSOUK ${ }^{2, v}$ \\ ${ }^{1}$ Plant and Invertebrate Taxonomy and Its Applications Unit Group, Biodiversity Program, Walai Rukhavej Botanical Research Institute, Mahasarakham \\ University. Kantarawichai, 44150 Maha Sarakham, Thailand \\ ${ }^{2}$ Plant and Invertebrate Taxonomy and Its Applications Unit Group, Department of Biology, Faculty of Science, Mahasarakham University. \\ Kantharawichai, 44150 Maha Sarakham, Thailand. Tel./fax.: +66-437-54245, `email: pcornukaempferia @yahoo.com
}

Manuscript received: 8 June 2021. Revision accepted: 26 July 2021.

\begin{abstract}
Saensouk S, Saensouk P. 2021. Karyotype analysis of three species of Allium (Amaryllidaceae) from Thailand. Biodiversitas 22: 3458-3466. Comprehensive karyotype analysis of three species of Allium from Thailand has not been reported. This work aims to study karyotype analysis of three species of Allium from Thailand. It is confusing due to the use of the common name or local name or local Thai name and morphologies. The karyotype analysis of three species with two variations in the genus Allium from Thailand were studied from root tips and observed under a microscope then karyotype was obtained from 10 metaphase plates. The chromosome numbers of them were found $2 \mathrm{n}=16$. The karyotype formulas of them were constructed as $14 \mathrm{~m}+2$ st $($ Allium ascalonicum $\mathrm{L}$. or shallot), $12 \mathrm{~m}+2 \mathrm{sm}+2 \mathrm{st}($. cepa $\mathrm{L}$. or onion), $10 \mathrm{~m}+6 \mathrm{sm}(1 \mathrm{sat})($. cepa $\mathrm{L}$. or red onion), $10 \mathrm{~m}+4 \mathrm{sm}+2 \mathrm{st}($ A. sativum $\mathrm{L}$. or big garlic or Chinese garlic) and $8 \mathrm{~m}+6 \mathrm{sm}+2 \mathrm{st}($ A. sativum $\mathrm{L}$. or small garlic or Thai garlic). Chromosome structure differences among the three species appeared in the number of $\mathrm{m}, \mathrm{sm}$ and st chromosomes and the satellites at the end of the short arm of $A$. cepa L. (red onion). This is new data on chromosome structure of the genus Allium. Moreover, the karyotype formulas, chromosome structures and satellites of this study should be used for classification of Allium from Thailand.
\end{abstract}

Keywords: chromosome number, satellite, karyotype, Allium, Amaryllidaceae

\section{INTRODUCTION}

The genus Allium L. was previously classified in the family Alliaceae, but has been reassigned to the family Amaryllidaceae (Fritsch et al. 2010). Allium consists of 1006 accepted species, making it one of the largest monocotyledonous genera (Maragheh et al. 2019, International Plant Names Index (IPNI) 2020, KewScience. 2021). In Thailand, Allium recognized ten species (Bangkok Forest Herbarium 2014). Allium is commonly used in Thai daily life and it is found in home gardens and produce markets. In Thailand, fresh or processed Allium species are economic plants that are used as herbs and for cooking. Various products, such as pickled garlic, fried garlic, shallots, pickled shallots and pickled onions, are processed from several species of this genus (Pholhiamhan et al. 2018).

Allium ascalonicum $\mathrm{L}$. and A. cepa $\mathrm{L}$. are commonly used to study cell division (both mitosis and meiosis) in various stages, due to the chromosomes of both species being large in size and clearly visible with a light microscope (Donsakul and Phornphisutthimas 2010, Maragheh et al. 2019). The karyotypes of many Allium species, from crops and ornamental plants, have been relatively poorly studied (Maragheh et al. 2019). Allium about 11 species, including A. cepa, A. aobonum, $A$. wakegi, A. oschanini, A. galantum, A. vavilovii, A. fistulosum, A. altaicum, A. ledebourianum, A. schoenoprasum and $A$. sativam have a chromosome number $2 n=16$ (Mensinkai 1939; Konvicka and Levan
1972; Seo and Kim 1975; Roy 1978; Verma and Mittal 1978; Vosa 1976; Chen 1989; Wajahatellah and Vahidy 1990; Puizina et al. 1995; Puizina and Papea 1996; Donsakul and Phornphisutthimas 2010; Mukherjee and Roy 2012; Maragheh et al. 2019). Except, some workers are found such as Kumar and Thonger (2018) reported chromosome numbers of the genus Allium from Nagaland, North-Eastern Region of India, namely A. chinense $(2 \mathrm{n}=$ $32)$, A. tuberosum $(2 \mathrm{n}=32)$, A. hookeri $(2 \mathrm{n}=22)$ and with basic chromosome number $(\mathrm{x}=8)$. Moreover, Mastall et al. (2018) studied chromosome numbers of and $A$. derderianum from Iran to be $2 n=18$. The previous karyology study of Allium was found $12 \mathrm{~m}+3 \mathrm{sm}+1 \mathrm{st}$ (A. ascalonicum from Kumar and Thonger (2018)), $12 \mathrm{~m}+4 \mathrm{sm}$ (A. sativum from Maragheh et al. (2019)) and $14 \mathrm{~m}+2 \mathrm{sm}(A$. sativum from Kumar and Thonger (2018)). In Thailand, Donsakul and Phornphisutthimas (2010) reported the chromosomes from root tips stained with Giemsa's stain and the karyotype formulas with $\mathrm{NF}$ of Allium ascalonicum L., A. cepa L. var. aggregatum G. Don, A. cepa var. viviparum (Metzg) Alef., A. fistulosum L., $A$. ampeloprasum L., A. sativum L. (large cloves), A. sativum L. (small cloves), and A. tuberosum Roxb. In addition from Donsakul and Phornphisutthimas (2010), the chromosome characteristics of Allium can be divided into two groups, i.e.: (i) onion group had satellite chromosomes, and (ii) garlic group had secondary constrictions on their chromosomes.

Currently, shallot, onion and garlic are found in several markets in the world especially in supermarkets, local 
markets and home gardens in villages (Pholhiamhan et al. 2018). However, their morphology is similar but differs in size, which is confusing due to the use of the common name or local name in each area in the world such as shallot and red onion (Donsakul and Phornphisutthimas 2010, Pholhiamhan et al. 2018). The karyotype analysis of three Allium species are associated mainly with comparisons among different species and varieties, and variations in chromosome number and karyotypes. Finally, chromosome structures and satellites of all species and all variations in this study should be not the same as previous report. It might be new chromosome data report of this genus. Therefore, the aim of this study is to study karyotype analysis of three species of Allium from Thailand.

\section{MATERIALS AND METHODS}

\section{Plant materials}

Three species and two variations of Allium, namely $A$. ascalonicum L. (shallot), A. cepa L. (onion), A. cepa L. (red onion), A. sativum L. (big garlic or Chinese garlic) and A. sativum L. (small garlic or Thai garlic), were collected from produce markets and home gardens in Maha Sarakham Province, Thailand. The cut roots were obtained from bulbs grown in pots in a nursery at the Walai Rukhavej Botanical Research Institute, Mahasarakham University, Thailand. In particular, shallots and red onions are both called shallots by most young Thai people (Table 1). All specimens were deposited at Mahasarakham University Herbarium. The comparative morphologies of all plant materials are presented in Table 1 and Figure 1.

\section{Karyotype observation and analysis}

Root tips (1.5-2 cm long) of all Allium specimens were pretreated with paradichlorobenzene (PDB) for 6 hours at $4^{\circ} \mathrm{C}$, fixed in ethanol-acetic acid (3:1, v:v) for $30 \mathrm{~min}$ at room temperature and stored at $4^{\circ} \mathrm{C}$ or immediately used. Samples were washed in distilled water, then hydrolyzed in $1 \mathrm{M} \mathrm{HCl}$ for $5 \mathrm{~min}$ at $60^{\circ} \mathrm{C}$ and washed again in distilled water. Root tips were stained and crushed in $2 \%$ acetoorcein (Saensouk and Saensouk 2021 a, b), and observed with taken photographs under a light microscope (Zeiss: Axiostar plus) at 100x magnification. Karyotype formulas were derived from measurements of the metaphase chromosomes in photomicrographs, obtained from 10 metaphase plates. The nomenclature of the chromosome shape for karyotype description followed Levan et al. (1964), Senavongse et al. (2018), Saensouk and Saensouk (2021 a, b). The classification of the karyotype symmetry followed Stebbins (1971), Senavongse et al. (2018), Saensouk and Saensouk (2021a, b).

\section{RESULTS AND DISCUSSION}

\section{Botanical nomenclature of Allium studied}

The botanical nomenclature of three species and two variations of the genus Allium, namely Allium ascalonicum L. (shallot), A. cepa L. (red onion), A. cepa L. (onion), A. sativum $\mathrm{L}$. (big garlic) and $A$. sativum $\mathrm{L}$. (small garlic), were sourced from plant list database (Maragheh et al. 2019, International Plant Names Index (IPNI) 2020, KewScience. 2021). A. ascalonicum L. (shallot), A. sativum L. (big garlic) and A. sativum L. (small garlic) are accepted names, while A. cepa L. (red onion) is an accepted name, but it has a synonym which is $A$. cepa $\mathrm{L}$. var. viviparum (Metzg) Alef.; A. cepa L. (onion) is an accepted name, while A. cepa L. var. aggregatum G. Don is a synonym of this species.

Table 1. Comparative analysis of morphological characteristics in three species of Allium with two variations of A. cepa and A. sativum from Thailand

\begin{tabular}{|c|c|c|c|c|c|c|c|}
\hline $\begin{array}{c}\text { Species of Allium } \\
\text { (common name/ local } \\
\text { Thai name) }\end{array}$ & $\begin{array}{l}\text { Pseudostem } \\
\text { height }(\mathbf{c m})\end{array}$ & $\begin{array}{l}\text { Diameter of } \\
\text { bulb }(\mathbf{c m})\end{array}$ & $\begin{array}{l}\text { Color of leaf sheaths } \\
\text { (Figure 1.A-E) }\end{array}$ & $\begin{array}{l}\text { Leaf size } \\
\quad(\mathrm{cm})\end{array}$ & Leaf shape & Cloves & $\begin{array}{l}\text { Collector } \\
\text { no. }\end{array}$ \\
\hline $\begin{array}{l}\text { A. ascalonicum L. } \\
\text { (shallot/Hom-Daeng) }\end{array}$ & $10-15$ & 2 & $\begin{array}{l}\text { Reddish when young } \\
\text { Red when mature } \\
\text { (Figure 1.A) }\end{array}$ & $\begin{array}{l}0.3-0.6 \mathrm{x} \\
7-10 \mathrm{~cm}\end{array}$ & $\begin{array}{l}\text { Linear with } \\
\text { tubular }\end{array}$ & - & $\begin{array}{l}\text { Saensouk } \\
3000\end{array}$ \\
\hline $\begin{array}{l}\text { A. сера } \mathrm{L} \text {. } \\
\text { (onion/Hom-Hua-Yai) }\end{array}$ & $35-40$ & $15-20$ & $\begin{array}{l}\text { Greenish-white or white } \\
\text { when young and mature } \\
\text { (Figure 1.B) }\end{array}$ & $\begin{array}{c}1-1.3 \mathrm{x} \\
27-35 \mathrm{~cm}\end{array}$ & $\begin{array}{l}\text { Linear with } \\
\text { tubular }\end{array}$ & - & $\begin{array}{l}\text { Saensouk } \\
3002\end{array}$ \\
\hline $\begin{array}{l}\text { A. сера } \mathrm{L} \text {. } \\
\text { (red onion/Hom-Khaek) }\end{array}$ & $25-30$ & 8 & $\begin{array}{l}\text { Dark red when young and } \\
\text { mature } \\
\text { (Figure 1.C) }\end{array}$ & $\begin{array}{l}0.8-0.9 \mathrm{x} \\
20-25 \mathrm{~cm}\end{array}$ & $\begin{array}{l}\text { Linear with } \\
\text { tubular }\end{array}$ & - & $\begin{array}{l}\text { Saensouk } \\
3001\end{array}$ \\
\hline $\begin{array}{l}\text { A. sativum L. } \\
\text { (small garlic or Thai } \\
\text { garlic/Kra-Tiam-Kleeb- } \\
\text { Lek) }\end{array}$ & $20-25$ & $5-7$ & $\begin{array}{l}\text { Grey when young and } \\
\text { mature } \\
\text { (Figure 1.D) }\end{array}$ & $\begin{array}{l}0.5-0.8 \mathrm{x} \\
15-20 \mathrm{~cm}\end{array}$ & $\begin{array}{l}\text { Broadly linear to } \\
\text { linear-lanceolate }\end{array}$ & $\begin{array}{l}\text { Small } \\
\text { cloves }\end{array}$ & $\begin{array}{l}\text { Saensouk } \\
3003\end{array}$ \\
\hline $\begin{array}{l}\text { A. sativum } \mathrm{L} \text {. } \\
\text { (big garlic or Chinese } \\
\text { garlic/Kra-Tiam-Kleeb- } \\
\text { Yai) }\end{array}$ & $35-40$ & $10-15$ & $\begin{array}{l}\text { Grey when young and } \\
\text { mature } \\
\text { (Figure 1.E) }\end{array}$ & $\begin{array}{c}1-1.2 \mathrm{x} \\
28-35 \mathrm{~cm}\end{array}$ & $\begin{array}{l}\text { Broadly linear to } \\
\text { linear-lanceolate }\end{array}$ & $\begin{array}{l}\text { Large } \\
\text { leaves }\end{array}$ & $\begin{array}{l}\text { Saensouk } \\
3004\end{array}$ \\
\hline
\end{tabular}




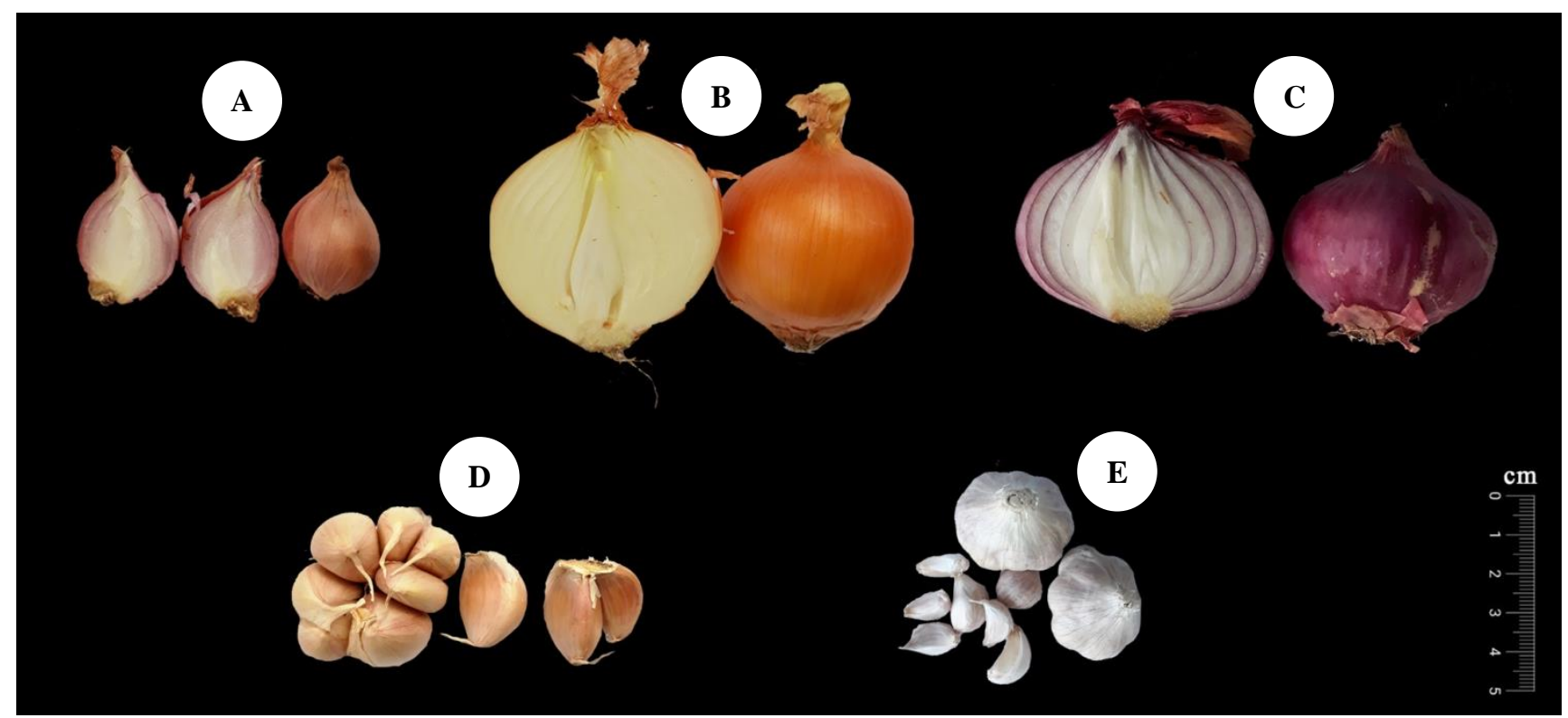

Figure 1. Morphology of bulbs from three species and two variations of Allium in Thailand: A. A. ascalonicum L. (shallot), B. A. cepa L. (onion), C. A. cepa L. (red onion), D. A. sativum L. (big garlic), E. A. sativum L. (small garlic). Scale bar $=5 \mathrm{~cm}$

\section{Karyotype analysis}

The studied chromosome numbers of three species and two variations, namely Allium ascalonicum L. (shallot), A. cepa L. (red onion), A. cepa L. (onion), A. sativum L. (big garlic) and A. sativum L. (small garlic), were found to be $2 n=16$ and this chromosome number agrees with a previous report by Donsakul and Phornphisutthimas (2010) who reported $2 n=16$. From result in this study (Table 2) found that the karyology study of Allium ascalonicum not consistent with the previous karyotype study by Donsakul and Phornphisutthimas (2010) and Kumar and Thonger (2018). Whereas, the karyotype of A. cepa L. (Red Onion) differs from the previous karyotype study by Donsakul and Phornphisutthimas (2010). Moreover, the karyotype of $A$. cepa L. (Onion) disagrees with the previous karyotype study by Donsakul and Phornphisutthimas (2010). The karyotype of A. sativum L. differs from the previous karyotype study by Donsakul and Phornphisutthimas (2010), Kumar and Thonger (2018) and Maragheh et al. (2019).

Allium ascalonicum has chromosome number of $2 n=$ 16 and its karyotype formula of $14 \mathrm{~m}+2$ st (Table 2) consists of seven pairs of metacentric (m) and one pair of subtelocentric (st) chromosomes (Table 3). The chromosomes have length short ranging from $4.37 \pm 0.58$ to $11.58 \pm 0.67 \mu \mathrm{m}$, length long ranging from $8.51 \pm 0.30$ to $14.21 \pm 0.58 \mu \mathrm{m}$, length total ranging from $14.35 \pm 0.88$ to $25.79 \pm 1.24 \mu \mathrm{m}$, relative length ranging from 8.91 to 16.02 $\%$ and centromeric index ranging from 0.50 to 0.76 (Table 3 , Figures $2 \mathrm{~A}$ and $3 \mathrm{~A}$ ). The number of chromosome arms (arm number, NF or FN) was found to being 32 (Table 2). This is consistent with the chromosome number $2 n=16$ reported by Aryavand (1975); Seo and Kim (1975); Vosa (1977); Pandita (1979); Cortes et al. (1983); Bartolo et al. (1984); Talukder and Sen (2000); and Donsakul and Phornphisutthimas (2010). Donsakul and Phornphisutthimas (2010) reported that karyotype formula of A. ascalonicum to be $12 \mathrm{~m}+2 \mathrm{sm}+2 \mathrm{st}$ (1 sat or one visible satellite chromosome) with $\mathrm{NF}=30$, which is not consistent with the karyotype formula with without visible satellite chromosome and NF of the present study results due to the effects of environmental factors such as water, air, soil and maybe nutrients (Saensouk and Saensouk 2021a, b).

Allium cepa (onion) has chromosome number $2 n=16$, and its karyotype formula of $12 m+2 s m+2 s t$ (Table 2) consists of six pairs of metacentric, one pair of submetacentric (sm), and one pair of subtelocentric chromosomes (Table 4). the chromosomes have length short ranging from $3.87 \pm 0.31$ to $8.78 \pm 0.33 \mu \mathrm{m}$, length long ranging from $7.25 \pm 0.33$ to $11.34 \pm 0.20 \mu \mathrm{m}$, length total ranging from $12.82 \pm 0.91$ to $18.42 \pm 0.68 \mu \mathrm{m}$, relative length ranging from 10.13 to $14.55 \%$ and centromeric index ranging from 0.51 to 0.75 (Table 4, Figures $2 \mathrm{~B}$ and 3B). The number of chromosome arms (arm number, NF or FN) is found to being 32 (Table 2). Donsakul and Phornphisutthimas (2010) reported that karyotype formula of $A$. cepa (onion) to be $12 \mathrm{~m}+2 \mathrm{sm}+2 \mathrm{st}$ ( 1 sat) with $\mathrm{NF}=$ 30 , which is the same as the karyotype formula in the present study results but differs in without visible satellites and NF due to the effects of environmental factors such as water, air, soil and maybe nutrients (Saensouk and Saensouk 2021a,b). 
Table 2. Chromosome number and karyotype analysis of three species and two variations of Allium from previous reports and the present study

\begin{tabular}{|c|c|c|c|c|c|c|}
\hline Species & $2 n$ & NF & Karyotype formula & $\begin{array}{c}\text { Visible } \\
\text { satellites }\end{array}$ & Location & Reference \\
\hline \multirow[t]{11}{*}{$\begin{array}{l}\text { A. ascalonicum } \\
\text { L. (shallot) }\end{array}$} & 16 & 32 & - & & $\begin{array}{l}\text { South } \\
\text { Korean }\end{array}$ & Seo and Kim (1975) \\
\hline & 16 & - & - & - & Iran & Aryavand (1975) \\
\hline & 16 & - & & & Brasil & Vosa (1977) \\
\hline & 16 & - & & & India & Pandita (1979) \\
\hline & 16 & - & & & - & Cortes et al. (1983) \\
\hline & 16 & - & & & Libya & Cortes et al. (1983) \\
\hline & 16 & - & & & - & Bartolo et al. (1984) \\
\hline & 16 & - & & & India & Talukder and Sen (2000) \\
\hline & 16 & - & $12 m+3 s m+1 s t$ & & India & Kumar and Thonger (2018) \\
\hline & 16 & 30 & $12 m+2 s m+2 s t$ & 1(STR) & Thailand & Donsakul and Phornphisutthimas (2010) \\
\hline & 16 & 32 & $14 m+2 s t$ & & Thailand & Present study \\
\hline \multirow{4}{*}{$\begin{array}{l}\text { A. ascalonicum } \\
\text { L. (shallot) }\end{array}$} & 16 & 32 & - & & South Korea & Seo and Kim (1975) \\
\hline & & & $12 m+3 s m+1 s t$ & & India & Kumar and Thonger (2018) \\
\hline & 16 & 30 & $12 m+2 s m+2 s t$ & 1(STR) & Thailand & Donsakul and Phornphisutthimas (2010) \\
\hline & 16 & 32 & $14 m+2 s t$ & & Thailand & Present study \\
\hline \multirow{8}{*}{$\begin{array}{l}\text { A. cepa } \mathrm{L} \text {. } \\
\text { (red onion) } \\
\text { (synonym = A. cepa } \\
\text { L. var. viviparum) }\end{array}$} & 16 & 30 & $10 m+4 s m+2 s t$ & $1(\mathrm{STR})$ & Thailand & Donsakul and Phornphisutthimas (2010) \\
\hline & 24 & 48 & - & - & India & Mukherjee and Roy (2012) \\
\hline & 16,24 & 32,48 & - & - & Croatian & Puizina et al. (1995) \\
\hline & 16 & - & - & - & Brasil & Vosa (1977) \\
\hline & 16 & - & - & - & India & Langer and Koul (1983) \\
\hline & 16,24 & 32,48 & - & - & Croatian & $\begin{array}{l}\text { Puizina and Papea } \\
\text { (1996) }\end{array}$ \\
\hline & 24 & - & - & - & India & Gohil and Kaul (1981) \\
\hline & 16 & 32 & $10 m+6 s m$ & 1(STR) & Thailand & Present study \\
\hline \multirow{6}{*}{$\begin{array}{l}\text { A. cepa } \mathrm{L} \text {. } \\
\text { (red onion) } \\
\text { (synonym = A. cepa } \\
\text { L. var. viviparum) }\end{array}$} & 16 & 30 & $10 m+4 s m+2 s t$ & $1(\mathrm{STR})$ & Thailand & Donsakul and Phornphisutthimas (2010) \\
\hline & 24 & 48 & - & - & India & Mukherjee and Roy (2012) \\
\hline & 16,24 & 32,48 & - & - & Croatian & Puizina et al. (1995) \\
\hline & 16,24 & 32,48 & - & - & Croatian & $\begin{array}{l}\text { Puizina and Papea } \\
\text { (1996) }\end{array}$ \\
\hline & 24 & - & - & - & India & Gohil and Kaul (1981) \\
\hline & 16 & 32 & $10 m+6 s m$ & 1(STR) & Thailand & Present study \\
\hline \multirow{5}{*}{$\begin{array}{l}\text { A. cepa } \mathrm{L} \text {. } \\
\text { (onion) (syn. A. cepa } \\
\text { L. var. aggregatum) }\end{array}$} & 16 & - & - & - & India & Vijayavalli and Mathew (1990) \\
\hline & 16 & 32 & - & - & Japan & Chen (1989) \\
\hline & 16 & 30 & $12 m+2 s m+2 s t$ & $1(\mathrm{STR})$ & Thailand & Donsakul and Phornphisutthimas (2010) \\
\hline & 16 & 32 & - & - & India & Mukherjee and Roy (2012) \\
\hline & 16 & 32 & $12 m+2 s m+2 s t$ & - & Thailand & Present study \\
\hline \multirow{18}{*}{$\begin{array}{l}\text { A. sativum L. (big } \\
\text { garlic) }\end{array}$} & 16 & - & - & - & - & Katayama (1928) \\
\hline & 16 & - & - & - & Sweden & Levan (1931) \\
\hline & 16 & - & - & - & Sweden & Levan (1935) \\
\hline & 16 & - & - & 1(STR) & - & Mensinkai (1939) \\
\hline & 16 & - & - & - & India & Khoshoo and Sharma (1959) \\
\hline & 16 & - & - & 2(STR) & India & Khoshoo et al. (1960) \\
\hline & 16 & & & 2 (STR) & - & Battaglia (1963) \\
\hline & 16 & 32 & - & - & Sweden & Konvicka and Levan (1972) \\
\hline & 32 & - & - & - & - & Novak (1974) \\
\hline & 16 & 32 & - & - & India & Verma and Mittal (1978) \\
\hline & 32 & - & - & - & India & Roy (1978) \\
\hline & & & & - & India & Verma and Mittal (1978) \\
\hline & 16 & - & - & - & India & Gohil and Kaul (1981) \\
\hline & 16 & - & - & - & India & Kumar and Subramaniam (1986) \\
\hline & 16 & - & - & - & India & Vijayavalli and Mathew (1990) \\
\hline & 16 & 32 & - & - & Pakistan & Wajahalatullah and Vahidy (1990) \\
\hline & 16 & 32 & - & - & India & Jacobkutty and Bhavanandan (1997) \\
\hline & 16 & 32 & $\begin{array}{l}6 \mathrm{~m}+2 \mathrm{sm}+2 \mathrm{t} \\
\text { (large cloves and } \\
\text { small cloves) }\end{array}$ & - & Thailand & Donsakul and Phornphisutthimas (2010) \\
\hline
\end{tabular}




\begin{tabular}{|c|c|c|c|c|c|c|}
\hline & 16 & 32 & - & - & India & Mukherjee and Roy (2012) \\
\hline & 32 & - & - & - & India & Manzum et al. (2014) \\
\hline & & & $14 m+2 s m$ & & India & Kumar and Thonger (2018) \\
\hline & 16 & 32 & $12 m+4 s m$ & - & Poland & Maragheh et al. (2019) \\
\hline & 16 & 32 & $10 m+4 s m+2 s t$ & - & Thailand & $\begin{array}{l}\text { Present study } \\
\text { (big garlic) }\end{array}$ \\
\hline \multirow{23}{*}{$\begin{array}{l}\text { A. sativum L. (small } \\
\text { garlic) }\end{array}$} & 16 & - & - & - & - & Katayama (1928) \\
\hline & 16 & - & - & - & Sweden & Levan (1931) \\
\hline & 16 & - & - & - & Sweden & Levan (1935) \\
\hline & 16 & - & - & $1(\mathrm{STR})$ & - & Mensinkai (1939) \\
\hline & 16 & - & - & - & India & Khoshoo and Sharma (1959) \\
\hline & 16 & - & - & 2(STR) & India & Khoshoo et al. (1960) \\
\hline & 16 & & & $2(\mathrm{STR})$ & - & Battaglia (1963) \\
\hline & 16 & 32 & - & - & Sweden & Konvicka and Levan (1972) \\
\hline & 32 & - & - & - & - & Novak (1974) \\
\hline & 16 & 32 & - & - & India & Verma and Mittal (1978) \\
\hline & 32 & - & - & - & India & Roy (1978) \\
\hline & & & & - & India & Verma and Mittal (1978) \\
\hline & 16 & - & - & - & India & Gohil and Kaul (1981) \\
\hline & 16 & - & - & - & India & Kumar and Subramaniam (1986) \\
\hline & 16 & - & - & - & India & Vijayavalli and Mathew (1990) \\
\hline & 16 & 32 & - & - & Pakistan & Wajahalatullah and Vahidy (1990) \\
\hline & 16 & 32 & - & - & India & Jacobkutty and Bhavanandan (1997) \\
\hline & 16 & 32 & $\begin{array}{l}6 \mathrm{~m}+2 \mathrm{sm}+2 \mathrm{t} \\
\text { (large cloves and } \\
\text { small cloves) }\end{array}$ & - & Thailand & Donsakul and Phornphisutthimas (2010) \\
\hline & 16 & 32 & - & - & India & Mukherjee and Roy (2012) \\
\hline & 32 & - & - & - & India & Manzum et al. (2014) \\
\hline & & & $14 \mathrm{~m}+2 \mathrm{sm}$ & & India & Kumar and Thonger (2018) \\
\hline & 16 & 32 & $12 m+4 s m$ & - & Poland & Maragheh et al. (2019) \\
\hline & 16 & 32 & $8 m+6 s m+2 s t$ & - & Thailand & $\begin{array}{l}\text { Present study } \\
\text { (small garlic) }\end{array}$ \\
\hline
\end{tabular}

Note: STR: subtelomeric region; NF: Fundamental Number

Table 3. Chromosome characteristic of Allium ascalonicum (shallot)

\begin{tabular}{cccccccc}
\hline Chromosome pair & $\mathbf{L s} \pm \mathbf{S D}(\boldsymbol{\mu m})$ & $\mathbf{L} \pm \mathbf{S D}(\boldsymbol{\mu m})$ & $\mathbf{L T} \pm \mathbf{S D}(\boldsymbol{\mu m})$ & $\mathbf{A R}$ & $\mathbf{R L}(\boldsymbol{\%})$ & $\begin{array}{c}\text { CI } \\
(\text { Structure) }\end{array}$ & Chromosome shape \\
\hline 1 & $11.58 \pm 0.67$ & $14.21 \pm 0.58$ & $25.79 \pm 1.24$ & 1.23 & 16.02 & 0.55 & Metacentric \\
2 & $11.56 \pm 0.88$ & $11.56 \pm 0.58$ & $23.11 \pm 1.46$ & 1.00 & 14.36 & 0.50 & Metacentric \\
3 & $9.14 \pm 0.74$ & $12.72 \pm 0.88$ & $21.86 \pm 1.62$ & 1.39 & 13.58 & 0.58 & Metacentric \\
4 & $8.73 \pm 0.42$ & $12.76 \pm 0.67$ & $21.49 \pm 1.08$ & 1.46 & 13.35 & 0.59 & Metacentric \\
5 & $8.56 \pm 0.88$ & $11.34 \pm 0.67$ & $19.90 \pm 1.55$ & 1.32 & 12.36 & 0.57 & Metacentric \\
6 & $4.37 \pm 0.58$ & $13.69 \pm 0.58$ & $18.05 \pm 1.15$ & 3.13 & 11.21 & 0.76 & Subtelocentric \\
7 & $7.87 \pm 0.58$ & $8.56 \pm 0.58$ & $16.43 \pm 1.15$ & 1.09 & 10.20 & 0.52 & Metacentric \\
8 & $5.84 \pm 0.58$ & $8.51 \pm 0.30$ & $14.35 \pm 0.88$ & 1.46 & 8.91 & 0.59 & Metacentric \\
\hline
\end{tabular}

Note: LA: length of the arm; p: long arm; q: short arm; TL: total arm length; CS: chromosome shape; AR: Arm Ratio

Allium cepa (red onion) has chromosome number of $2 n$ $=16$, and its karyotype formula of $10 \mathrm{~m}+6 \mathrm{sm}(1 \mathrm{sat})$ consists of five pairs of metacentric, three pairs of submetacentric chromosomes and one visible satellite at the end of the short arm, pair 6, bar 11 of the submetacentric chromosome (Table 4). The chromosomes have length short ranging from $4.63 \pm 0.33$ to $9.13 \pm 0.33 \mu \mathrm{m}$, length long ranging from $7.10 \pm 0.33$ to $10.49 \pm 0.33 \mu \mathrm{m}$, length total ranging from $11.92 \pm 0.67$ to $19.62 \pm 0.67 \mu \mathrm{m}$, relative length ranging from 9.72 to $15.99 \%$ and centromeric index ranging from 0.53 to 0.65 (Table 4, Figures $2 \mathrm{C}$ and $3 \mathrm{C}$ ). The number of chromosome arms (arm number, NF or FN) is found to being 32 (Table 2). The present results agree with the previous studies by Vosa (1977), Langer and Koul (1983) and Puizina and Papea (1996), while Mukherjee and Roy (2012); Puizina et al. (1995); Puizina and Papea (1996). Gohil and Kaul (1981) reported a chromosome number of $2 n=3 \mathrm{x}=24$, which disagrees with this study. In addition, the karyotype formula of this species is $10 \mathrm{~m}+4 \mathrm{sm}+2 \mathrm{st}$ with one visible satellite ( $\mathrm{NF}=30)$, (Donsakul and Phornphisutthimas 2010) which is different from the karyotype formula of the present study due to the effects of environmental factors, and NF is different in this study results $(\mathrm{NF}=32)$ also due 
to the effects of environmental factors such as water, air, soil and maybe nutrients (Saensouk and Saensouk 2021a, b).

The present study shows the chromosome numbers of A. cepa (onion) and A. cepa (red onion) are the same, but have differences in the karyotype formula $12 \mathrm{~m}+2 \mathrm{sm}+2 \mathrm{st}$ of $A$. cepa. (onion) and $10 \mathrm{~m}+6 \mathrm{sm}$ (1 sat) of $A$. cepa (red onion) and one visible satellite due to differences in the morphology of both variations of onions (Table 1), i.e. the pseudostem, including the bulb, and leaves of red onion are shorter and smaller than the pseudostem of onion; the color of the leaf sheaths of red onion has a dark red color when young and mature, while the color of the leaf sheaths of onion has been found to be greenish-white or white when young and mature. While, the scientific name of onion and red onion from many literature studies and international databases, such as http://www.ipni.org (International Plant Names Index (IPNI) 2020) and http://apps.kew.org/wcsp/ (KewScience 2021), were found to be the same for both variations, indicating both are the same species. Therefore, differences in the karyotype formula, chromosome structure of both variations (onion and red onion) due to the variation in morphology and effects of environmental factors such as water, air, soil and maybe nutrients (Saensouk and Saensouk 2021a,b).

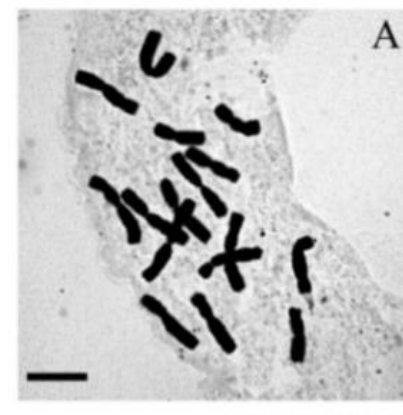

A
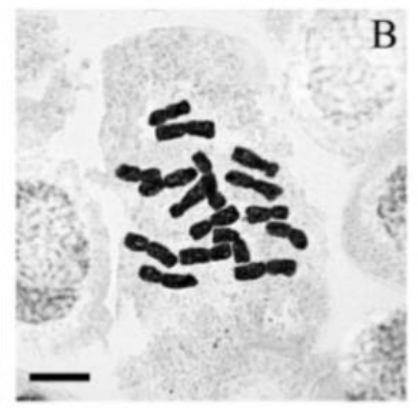

B

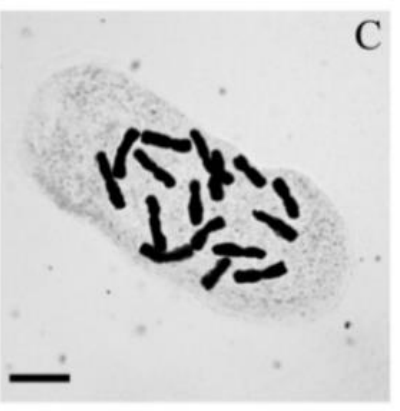

D

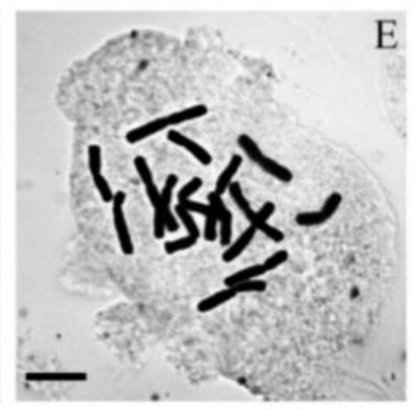

Figure 2. Somatic chromosome at metaphase of: A. A. ascalonicum (shallot), B. A. cepa (onion), C. A. cepa (red onion), D. A. sativum (big garlic or Chinese garlic), and E. A. sativum (small garlic or Thai garlic). Scale bars $=10 \mu \mathrm{m}$

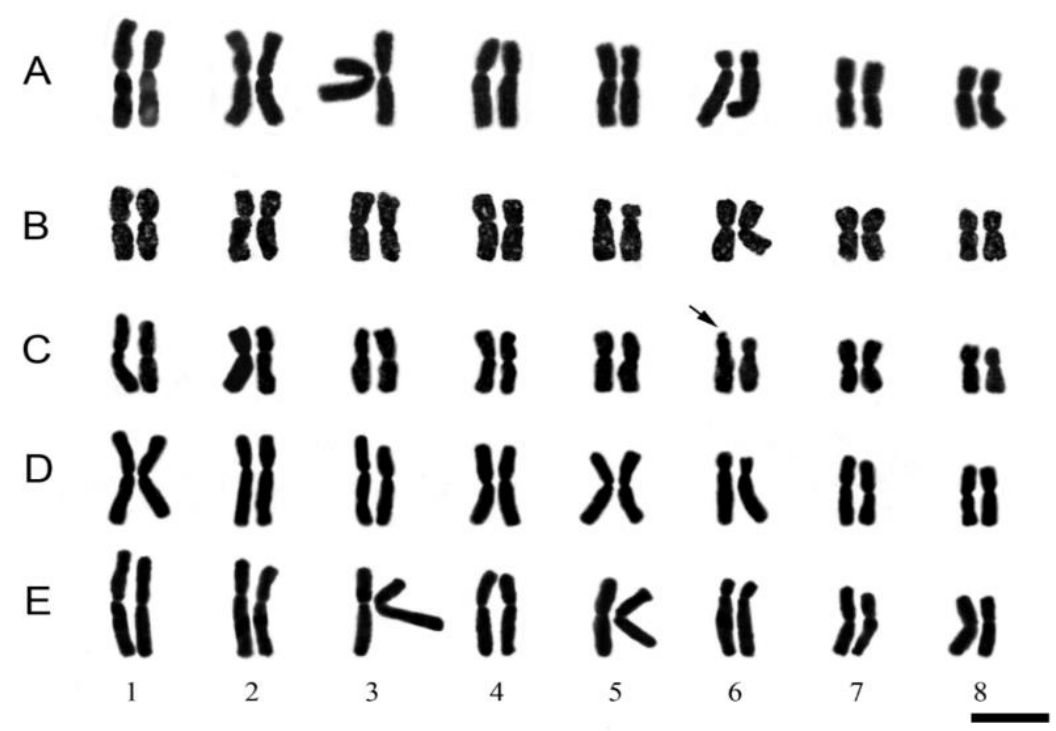

Figure 3. Karyotypes of: A. A. ascalonicum (shallot), B. A. cepa (onion), C. A. cepa (red onion), D. A. sativum (big garlic or Chinese garlic), and E. A. sativum (small garlic or Thai garlic). Arrows indicate satellite. Scale bar $=10 \mu \mathrm{m}$ 
Allium sativum (big garlic) was determined to have the chromosome number $2 n=16$, and its karyotype formula of $10 m+4 s m+2 s t$, consists of five pairs of metacentric, two pairs of submetacentric and one pair of subtelocentric chromosomes (Table 5). the chromosomes have length short ranging from $4.23 \pm 0.44$ to $11.09 \pm 0.44 \mu \mathrm{m}$, length long ranging from $8.06 \pm 0.50$ to $14.79 \pm 0.58 \mu \mathrm{m}$, length total ranging from $15.12 \pm 0.91$ to $23.44 \pm 0.88 \mu \mathrm{m}$, relative length ranging from 9.69 to $15.02 \%$ and centromeric index ranging from 0.53 to 0.75 (Table 5 , Figures $2 \mathrm{D}$ and 3D). The number of chromosome arms (arm number, NF or FN) is found to being 32 (Table 2). The chromosome number in this study is $2 n=16$, which agrees with Katayama (1928), Levan (1931 and 1935), Mensinkai (1939), Khoshoo and Sharma (1959), Khoshoo et al. (1960), Roy (1978), Verma and Mittal (1978), Kumar and Subramaniam (1986), Wajahalatullah and Vahidy (1990), Jacobkutty and Bhavanandan (1997), and Mukherjee and Roy (2012). while, Sharma and Bal (1959) reported the chromosome number $2 n=18$ and Novak (1974) and Manzum et al. (2014) reported the chromosome number $2 n=32$, which are different from this study results. Moreover, Khoshoo et al. (1960); and Battaglia (1963) found $2 n=16$ with two satellite pairs, except Mensinkai (1939) which found only one satellite pair and differs from the current study. Donsakul and Phornphisutthimas (2010) recognized the karyotype formula $6 \mathrm{~m}+2 \mathrm{sm}+2 \mathrm{t}$ with $\mathrm{NF}=32$ of large cloves (big garlic in this study) which disagrees with this study results due to the effects of environmental factors such as water, air, soil and maybe nutrients (Saensouk and Saensouk 2021a, b), while NF is the same in this study (NF = 32).
Allium sativum (small garlic) was determined to have the chromosome number $2 n=16$ and its karyotype formula of $8 m+6 s m+2 s t$ consists of four pairs of metacentric, three pairs of submetacentric and one pair of subtelocentric chromosomes (Table 5). the chromosomes have length short ranging from $4.50 \pm 0.71$ to $12.50 \pm 0.58 \mu \mathrm{m}$, length long ranging from $8.30 \pm 0.44$ to $15.58 \pm 0.82 \mu \mathrm{m}$, length total ranging from $15.42 \pm 1.02$ to $26.90 \pm 1.34 \mu \mathrm{m}$, relative length ranging from 9.33 to $16.26 \%$ and centromeric index ranging from 0.54 to 0.77 (Table 5 , Figures $2 \mathrm{E}$ and $3 \mathrm{E}$ ). The number of chromosome arms (arm number, NF or FN) is found to being 32 (Table 2). The chromosome number of this study is consistent with the studies of several workers (Katayama 1928; Levan 1931 and 1935; Mensinkai 1939; Khoshoo and Sharma 1959; Khoshoo et al. 1960; Roy 1978; Verma and Mittal 1978; Kumar and Subramaniam 1986; Wajahalatullah and Vahidy 1990; Jacobkutty and Bhavanandan 1997; and Mukherjee and Roy 2012;). While, Novak (1974) and Manzum et al. (2014) reported the chromosome number $2 \mathrm{n}=32$, which is not consistent with the present study. The chromosome number $2 n=16$ with two satellite pairs was earlier reported (Khoshoo et al. 1960; Battaglia 1963; and Mensinkai 1939, while Mensinkai (1939) found only one satellite pair, which differs from current study. Donsakul and Phornphisutthimas (2010) recognized the karyotype formula $6 \mathrm{~m}+2 \mathrm{sm}+2 \mathrm{t}$ with $\mathrm{NF}=32$ of small cloves (small garlic in this study). The karyotype formula differs from this study due to the effects of environmental factors. NF is different in this study results due to effects of environmental factors such as water, air, soil and maybe nutrients (Saensouk and Saensouk 2021a, b).

Table 4. Comparison of chromosome characteristics of Allium cepa (onion) and A. cepa (red onion)

\begin{tabular}{|c|c|c|c|c|c|c|c|c|}
\hline Species & $\begin{array}{c}\text { Chromosome } \\
\text { pair }\end{array}$ & $\begin{array}{c}\text { Ls } \pm \text { SD } \\
(\mu \mathrm{m})\end{array}$ & $\begin{array}{c}\mathrm{Ll} \pm \mathrm{SD} \\
(\mu \mathrm{m})\end{array}$ & $\begin{array}{c}\mathbf{L T} \pm \mathbf{S D} \\
(\mu \mathrm{m})\end{array}$ & $\mathbf{A R}$ & $\begin{array}{l}\text { RL } \\
(\%)\end{array}$ & $\begin{array}{c}\text { CI } \\
\text { (Structure) }\end{array}$ & $\begin{array}{c}\begin{array}{c}\text { Chromosome } \\
\text { shape }\end{array} \\
\end{array}$ \\
\hline \multirow{8}{*}{$\begin{array}{l}\text { A. cepa } \mathrm{L} \text {. } \\
\text { (onion) }\end{array}$} & 1 & $8.49 \pm 0.35$ & $9.94 \pm 0.33$ & $18.42 \pm 0.68$ & 1.17 & 14.55 & 0.54 & Metacentric \\
\hline & 2 & $6.72 \pm 0.33$ & $11.34 \pm 0.20$ & $18.06 \pm 0.53$ & 1.69 & 14.26 & 0.63 & Submetacentric \\
\hline & 3 & $8.78 \pm 0.33$ & $8.98 \pm 0.30$ & $17.76 \pm 0.63$ & 1.02 & 14.03 & 0.51 & Metacentric \\
\hline & 4 & $6.47 \pm 0.30$ & $9.63 \pm 0.33$ & $16.10 \pm 0.63$ & 1.49 & 12.72 & 0.59 & Metacentric \\
\hline & 5 & $3.87 \pm 0.31$ & $11.44 \pm 0.44$ & $15.32 \pm 0.75$ & 2.96 & 12.10 & 0.75 & Subtelocentric \\
\hline & 6 & $6.77 \pm 0.33$ & $8.08 \pm 0.33$ & $14.85 \pm 0.67$ & 1.19 & 11.73 & 0.54 & Metacentric \\
\hline & 7 & $5.96 \pm 0.33$ & $7.33 \pm 0.33$ & $13.29 \pm 0.67$ & 1.23 & 10.50 & 0.55 & Metacentric \\
\hline & 8 & $5.57 \pm 0.58$ & $7.25 \pm 0.33$ & $12.82 \pm 0.91$ & 1.30 & 10.13 & 0.57 & Metacentric \\
\hline \multirow{8}{*}{$\begin{array}{l}\text { A. cepa L. (red } \\
\text { onion) }\end{array}$} & 1 & $9.13 \pm 0.33$ & $10.49 \pm 0.33$ & $19.62 \pm 0.67$ & 1.15 & 15.99 & 0.53 & Metacentric \\
\hline & 2 & $6.66 \pm 0.13$ & $10.38 \pm 0.33$ & $17.04 \pm 0.47$ & 1.56 & 13.89 & 0.61 & Submetacentric \\
\hline & 3 & $7.01 \pm 0.33$ & $8.71 \pm 0.30$ & $15.71 \pm 0.63$ & 1.24 & 12.81 & 0.55 & Metacentric \\
\hline & 4 & $7.38 \pm 0.33$ & $8.32 \pm 0.33$ & $15.70 \pm 0.67$ & 1.13 & 12.80 & 0.53 & Metacentric \\
\hline & 5 & $6.61 \pm 0.33$ & $8.38 \pm 0.33$ & $14.99 \pm 0.67$ & 1.27 & 12.22 & 0.56 & Metacentric \\
\hline & $6^{*}$ & $4.96 \pm 0.43$ & $9.37 \pm 0.33$ & $14.34 \pm 0.77$ & 1.89 & 11.69 & 0.65 & Submetacentric \\
\hline & 7 & $6.24 \pm 0.33$ & $7.10 \pm 0.33$ & $13.34 \pm 0.67$ & 1.14 & 10.87 & 0.53 & Metacentric \\
\hline & 8 & $4.63 \pm 0.33$ & $7.29 \pm 0.33$ & $11.92 \pm 0.67$ & 1.58 & 9.72 & 0.61 & Submetacentric \\
\hline
\end{tabular}

Notes: *: satellite chromosome, LA: length of the arm; p: long arm; q: short arm; TL: total arm length; CS: chromosome shape; AR: Arm Ratio. 
Table 5. Comparison of chromosome characteristic of A. sativum (big garlic or Chinese garlic) and A. sativum (small garlic or Thai garlic)

\begin{tabular}{|c|c|c|c|c|c|c|c|c|}
\hline Species & $\begin{array}{c}\text { Chromosome } \\
\text { pair }\end{array}$ & $\begin{array}{c}\text { Ls } \pm \text { SD } \\
(\mu \mathrm{m})\end{array}$ & $\begin{array}{c}\mathrm{Ll} \pm \mathrm{SD} \\
(\mu \mathrm{m})\end{array}$ & $\begin{array}{c}\mathbf{L T} \pm \text { SD } \\
(\mu \mathrm{m})\end{array}$ & AR & $\begin{array}{l}\text { RL } \\
(\%)\end{array}$ & $\begin{array}{c}\text { CI } \\
\text { (Structure) }\end{array}$ & $\begin{array}{c}\text { Chromosome } \\
\text { shape }\end{array}$ \\
\hline A. sativum L. (big & 1 & $11.09 \pm 0.44$ & $12.35 \pm 0.44$ & $23.44 \pm 0.88$ & 1.11 & 15.02 & 0.53 & Metacentric \\
\hline garlic or Chinese & 2 & $8.45 \pm 0.28$ & $14.79 \pm 0.58$ & $23.24 \pm 0.85$ & 1.75 & 14.89 & 0.64 & Submetacentric \\
\hline \multirow[t]{6}{*}{ garlic) } & 3 & $8.57 \pm 0.44$ & $12.88 \pm 0.42$ & $21.45 \pm 0.86$ & 1.50 & 13.74 & 0.60 & Submetacentric \\
\hline & 4 & $9.21 \pm 0.58$ & $11.12 \pm 0.44$ & $20.32 \pm 1.02$ & 1.21 & 13.02 & 0.55 & Metacentric \\
\hline & 5 & $8.80 \pm 0.56$ & $10.32 \pm 0.39$ & $19.12 \pm 0.96$ & 1.17 & 12.25 & 0.54 & Metacentric \\
\hline & 6 & $4.23 \pm 0.44$ & $12.79 \pm 0.44$ & $17.02 \pm 0.88$ & 3.03 & 10.90 & 0.75 & Subtelocentric \\
\hline & 7 & $7.35 \pm 0.58$ & $9.01 \pm 0.58$ & $16.36 \pm 1.15$ & 1.22 & 10.48 & 0.55 & Metacentric \\
\hline & 8 & $7.06 \pm 0.41$ & $8.06 \pm 0.50$ & $15.12 \pm 0.91$ & 1.14 & 9.69 & 0.53 & Metacentric \\
\hline A. sativum $\mathrm{L}$. & 1 & $12.50 \pm 0.58$ & $14.39 \pm 0.76$ & $26.90 \pm 1.34$ & 1.15 & 16.28 & 0.54 & Metacentric \\
\hline (small garlic or & 2 & $8.59 \pm 0.58$ & $15.58 \pm 0.82$ & $24.17 \pm 1.26$ & 1.81 & 14.63 & 0.64 & Submetacentric \\
\hline \multirow[t]{6}{*}{ Thai garlic) } & 3 & $7.59 \pm 0.82$ & $13.76 \pm 0.44$ & $21.95 \pm 1.26$ & 1.81 & 13.29 & 0.63 & Submetacentric \\
\hline & 4 & $8.91 \pm 0.83$ & $12.93 \pm 0.62$ & $21.24 \pm 1.45$ & 1.45 & 12.86 & 0.61 & Submetacentric \\
\hline & 5 & $9.12 \pm 0.71$ & $10.92 \pm 0.82$ & $20.04 \pm 1.53$ & 1.20 & 12.13 & 0.55 & Metacentric \\
\hline & 6 & $4.50 \pm 0.71$ & $15.38 \pm 0.76$ & $19.89 \pm 1.47$ & 3.42 & 12.04 & 0.77 & Subtelocentric \\
\hline & 7 & $6.82 \pm 0.83$ & $8.77 \pm 0.58$ & $15.60 \pm 1.41$ & 1.29 & 9.44 & 0.56 & Metacentric \\
\hline & 8 & $7.12 \pm 0.58$ & $8.30 \pm 0.44$ & $15.42 \pm 1.02$ & 1.17 & 9.33 & 0.54 & Metacentric \\
\hline
\end{tabular}

Note: LA: length of the arm; p: long arm; q: short arm; TL: total arm length; CS: chromosome shape; AR: Arm Ratio.

This study showed that the chromosome numbers with NF of Allium sativum (big garlic) and A. sativum (small garlic) are the same which is the same with study of Donsakul and Phornphisutthimas (2010), but differ in the karyotype formula, chromosome structure due to differences in the size of the morphology in both variations of garlic, i.e. big garlic has large cloves with large leaves, while small garlic has small cloves with small leaves (Table 1) and because of the effects of environmental factors such as water, air, soil and maybe nutrients (Saensouk and Saensouk 2021a, b) which disagrees with studied of Donsakul and Phornphisutthimas (2010) because they reported the same in karyotype formula and chromosome structure of variations of garlic.

Such discrepancies in karyotype formula were probably due to differences in analyzed materials and mitotic stages used, and difficulty in identifying chromosomes using the classical staining technique before (She et al. 2015a, 2015b, 2017, 2020). This observed difference could mainly be related to variation in the chromosome condensation levels of measured cells (She et al. 2015a, 2020). Therefore, differences in the chromosome structures due to the variation in morphology of Allium species, such as variation in cloves of both variations garlic, in size and color of both variation onion (Table 1) and because of the effects of environmental factors such as water, air, soil and maybe nutrients (Saensouk and Saensouk 2021a, b).

In conclusion, The somatic chromosome number of Allium ascalonicum (shallot), A. cepa (red onion), A. cepa (onion), A. sativum (big garlic) and A. sativum (small garlic) in this study are found the same number $2 n=16$. The chromosome structure differences among the three species appeared in the number of $\mathrm{m}, \mathrm{sm}$ and $\mathrm{st}$ chromosomes and the visible satellites, which are the visible bands at the end of the short arm of the chromosome structure of A. cepa (red onion). chromosome structures and satellites of all species and all variations in this study are not the same. chromosome structures and satellites of this study could be used for classification in Allium ascalonicum (shallot), A. cepa (onion), A. cepa (red onion), A. sativum (big garlic or Chinese garlic) and $A$. sativum (small garlic or Thai garlic) from Thailand.

\section{ACKNOWLEDGEMENTS}

This research project was financially supported by Mahasarakham University, Thailand. We are deeply indebted to the Walai Rukhavej Botanical Research Institute and the Center of Excellence for Silk Innovation, Division of Research Facilitation and Dissemination, Mahasarakham University, Thailand, for their facilities during this study. Many thanks to Dr. Jolyon Dodgson, (Myerscough College, Preston, UK) for language editing and suggestions to improve the manuscript.

\section{REFERENCES}

Aryavand A. 1975. Contribution al'etude cytotaxonomique de quelquesangiospermes de 1' Iran. Bot Not 128: 299-311.

Bangkok Forest Herbarium. 2014. Thai Plant Names Tem Smitinand Revised Edition 2014. Bangkok, Thailand.

Bartolo G, Brullo S, Pavone P, Terrasi MC. 1984. Cytotaxonomical notes on some Liliaceae of N Cyrenaica. Webbia 38: 601-622. DOI: 10.1080/00837792.1984.10670329.

Battaglia E. 1963. Mutazione chromosomica e cariotipo fondamentale in Allium sativum L. Caryologia 16: 1-46. DOI: 10.1080/00087114.1963.10796082.

Chen Ry. 1989. A further research of plant chromosome G-banding. In: D. Hong (ed.). Plant Chromosome Research. Nishiki Print Co, Hiroshima.

Cortes F, Gonzalez-Gil G, Hazen MJ. 1983. C-Banding and sister chromatid exchanges in three species of the genus Allium (A. cepa, A. ascalonicum and A. sativum). Caryologia 36: 203-210. DOI: 10.1080/00087114.1983.10797661. 
Donsakul T, Phornphisutthimas S. 2010. Karyotypes of six species in Allium (Alliaceae) in Thailand. Naresuan Univ J 18: 34-39. [Thailand]

Fritsch RM, Blattner FR, Gurushidze M. 2010. New classification of Allium L. subg. melanocrommyum (Webb \&amp; Berthel.) Rouy (Alliaceae) based on molecular and morphological characters. Phyton 49: $145-220$

Gohil RN, Kaul R. 1981. In Chromosome number reports LXXII. Taxon 30: 707.

International Plant Names Index (IPNI). 2020. http://www.ipni.org; Accessed 30 May 2021.

Jacobkutty MI, Bhavanandan KV. 1997. Karyotype studies in Allium sativum. J Cytol Genet 32: 125-128.

Katayama Y. 1928. The chromosome number in Phaseolus and Allium, and an observation on the size of stomata in different species of Triticum. J Sci Agric Soc Tokyo 303: 52-54.

KewScience. 2021. World Checklist of Selected Plant Families (WCSP) http://apps.kew.org/wcsp/ Accessed 30 May 2021.

Khoshoo TN, Atal CK, Sharma VB. 1960. Cytotaxonomical and chemical investigations on the northwest Indian garlic. Res Bull Panj Univ 28 $37-47$.

Khoshoo TN, Sharma VB. 1959. Chromosome number of north Indian garlic. Curr Sci 26: 62.

Konvicka O, Levan A. 1972. Chromosome studies in Allium sativum Hereditas 72: 129-148. DOI: 10.1111/j.1601-5223.1972.tb01035.x.

Kumar S, Thonger T. 2018. Karyomorphology of five Allium species from Nagaland, North-Eastern Region of India. Jordan J Biol Sci 11 (1): 9

Kumar V, Subramaniam, B. 1986. Chromosome Atlas of Flowering Plants of the Indian Subcontinent, Monocotyledons. Botanical Survey of India, Calcutta.

Langer A, Koul AK. 1983. Studies on nucleolus and nucleolar chromosomes in angiosperms VII. Nature of nucleolar chromosome polymorphism in Allium cepa var. viviparum (Metzg) Alef. Cytologia 48: 323-332. DOI: 10.1508/cytologia.48.323

Levan A, Fredya K, Sandberg AA. 1964. Nomenclature for centromeric position on chromosome. Hereditas 52: 201-220. DOI: 10.1111/j.1601-5223.1964.tb01953.x.

Levan A. 1931. Cytological studies in Allium. A preliminary note. Heriditas 15: 347-356. DOI: 10.1111/j.1601-5223.1931.tb02557.x.

Levan A. 1935. Cytological studies in Allium VI. The chromosome morphology of some diploid species of Allium. Hereditas 20: 289330. DOI: 10.1111/j.1601-5223.1935.tb03192.x.

Manzum AA, Sultana SS, Warasy AA, Begum R, Alam SS. 2014 Characterization of four specimens of Allium sativum L. by differential karyotype and RAPD analysis. Cytologia 79: 419-426. DOI: $10.1508 /$ cytologia.79.419.

Maragheh FP, Janus D, Senderowicz M, Haliloglu K, Kolano B. 2019. Karyotype analysis of eight cultivated Allium species. J Appl Genet 60: 1-11. DOI: 10.1007/s13353-018-0474-1.

Mastall H, Zare-Mehrjerdi, M, Norouzim, Rezaei J. 2018 Karyomorphological variations in some populations of Allium subgenus Melanocrommyum section Acanthoprason in Iran. Biodiversitas 19 (2): 720-725. DOI: 10.13057/biodiv/d190246.

Mensinkai SW. 1939. Cytogenetic studies in the genus Allium. J Genet 39 1-45. DOI: $10.1007 / \mathrm{BF} 02982816$.

Mukherjee A, Roy SC. 2012. Karyotype analysis of five species of Allium Indian J Fund Appl Life Sci 2: 374-383.

Novak FJ. 1974. The changes of karyotype in callus cultures of Allium sativum L. Caryologia 27: 45-54. DOI: 10.1080/00087114.1974.10796560
Pandita TK. 1979. Cytological investigations of some monocots of Kashmir. [Dissertation]. Chandigarh University, Chandigarh State.

Pholhiamhan R, Saensouk S, Saensouk P. 2018. Ethnobotany of Phu Thai ethnic group in Nakhon Phanom Province, Thailand. Walailak J Sci Technol 15 (10): 679-699. DOI: 10.48048/wjst.2018.3737.

Puizina J, Papea D. 1996. Cytogenetical evidence for hybrid structure and origin of diploid and triploid shallots (Allium cepa var. viviparum, Liliaceae) from Dalmatia (Croatia). Pl Syst Evol 199: 203-215. DOI: 10.1007/BF00984905

Puizina J, Solic ME, Papes D. 1995. Mediterranean chromosome number reports 5 (524-527). Fl Medit 5: 337-340.

Roy SC. 1978. Polymorphism in Giemsa banding pattern in Allium sativum. Cytologia 43: 97-100. DOI: 10.1508/cytologia.43.97.

Saensouk P, Saensouk S. 2021a. Diversity and cytological studies on the genus Amomum Roxb. former Elettariopsis Baker (Zingiberaceae) in Thailand. Biodiversitas 22 (6): 3209-3218. DOI: 10.13057/biodiv/d220624.

Saensouk S, Saensouk P. 2021b. Comparative chromosomal features for four Apocynaceae species from Northeastern Thailand. Biologia (2021). DOI 10.1007/s11756-021-00783-0.

Seo BB, Kim JH. 1975. Karyotypic analyses based on heterochromatin distribution in Allium fistulosum and Allium ascalonicum. Korean J Bot 18: 92-100

Sharma AK, Bal AK. 1959. A study of spontaneous fragmentation in two varieties of Allium sativum and interpretation of their karyotypes. In Proc. 46th Indian Science Congress Association, New Delhi.

She CW, Jiang XH, Ou LJ, Liu J, Long KL, Zhang LH, Duan WT, Zhao W, Hu JC. 2015b. Molecular cytogenetic characterisation and phylogenetic analysis of the seven cultivated Vigna species (Fabaceae). Plant Biol 17: 268-280. DOI: 10.1111/plb.12174.

She CW, Jiang XH. 2015a. Karyotype analysis of Lablab purpureus (L.) Sweet using fluorochrome banding and fluorescence in situ hybridization with rDNA probes. Czech J Genet Plant Breed 51 (3): 110-116. DOI: 10.17221/32/2015-CJGPB.

She CW, Mao Y, Jiang XH, He CP. 2020. Comparative molecular cytogenetic characterization of five wild Vigna species (Fabaceae). $\begin{array}{llll}\text { Comp } & \text { Cytogenet } 14 & \text { (2): 243-264. DOI: }\end{array}$ 10.3897/CompCytogen.v14i2.51154.

She CW, Wei L, Jiang XH. 2017. Molecular cytogenetic characterization and comparison of the two cultivated Canavalia species (Fabaceae). $\begin{array}{lllll}\text { Comp } & \text { Cytogenet } & 11 & \text { (4): }\end{array}$ 10.3897/compcytogen.v11i4.13604.

Stebbins GL. 1971. Chromosomal Evolution in Higher Plants. Addison Wesley Publishing Co., CA.

Talukder K, Sen S. 2000. Chromosome characteristics in some Allium spp. and assessment of their interrelationship. Nucleus (Calcutta) 43: 46-57.

Verma SC, Mittal RK. 1978. Chromosome variation in the common garlic, Allium sativum L. Cytologia 43: 383-396. DOI: 10.1508/cytologia.43.383

Vijayavalli B, Mathew PM. 1990. Cytotax. Liliaceae Allied Fam. India: Continental Publishers, Kerala.

Vosa CG. 1976. Heterochromatic patterns in Allium 1. The relationship between the species of the Cepa group and its allies. Heredity 36: 383-392. DOI: 10.1038/hdy.1976.45.

Vosa CG. 1977. Heterochromatic patterns and species relationship. Nucleus 20: 33-41.

Wajahatullah MK, Vahidy A. 1990. Karyotyping and localization of nucleolar organizer regions in garlic Allium sativum L. Cytologia 53: 501-504. DOI: 10.1508/cytologia.55.501. 